\title{
Biochemical and Pathological Studies on Peroxidases -An Updated Review
}

\author{
Amjad A. Khan ${ }^{1}$, Arshad H. Rahmani ${ }^{2}$, Yousef H. Aldebasi ${ }^{3} \&$ Salah M. Aly ${ }^{2,4}$ \\ ${ }^{1}$ Department of Basic Health Sciences, College of Applied Medical Science, Qassim University, Qassim, \\ Buraidah, Saudi Arabia \\ ${ }^{2}$ Department of Medical Laboratories, College of Applied Medical Science, Qassim University, Qassim, \\ Buraidah, Saudi Arabia \\ ${ }^{3}$ Department of Optometry College of Applied Medical Science, Qassim University, Qassim, Buraidah, Saudi \\ Arabia \\ ${ }^{4}$ Department of Pathology, Faculty of Veterinary Medicine, Suez Canal University, Ismalia, Egypt \\ Correspondence: Amjad Ali Khan, Department of Basic Health Sciences, College of Applied Medical Sciences, \\ Qassim University, Qassim, Kingdom of Saudi Arabia. Tel: 966-16-380-1266, Fax: 966-16-380-1628. E-mail: \\ akhan@qu.edu.sa,amjadbc@gmail.com
}

Received: April 4, 2014 Accepted: April 27, 2014 Online Published: May 13, 2014

doi:10.5539/gjhs.v6n5p87 URL: http://dx.doi.org/10.5539/gjhs.v6n5p87

\begin{abstract}
Peroxidases represent a family of isoenzymes actively involved in oxidizing reactive oxygen species, innate immunity, hormone biosynthesis and pathogenesis of several diseases. Different types of peroxidases have organ, tissues, cellular and sub-cellular level of specificities in their function. Different diseases lead to varied expressions of peroxidases based on several mechanisms proposed. Several researches are going on to understand its deficiency, over-expression and malfunction in relation with different diseases. Some common diseases of mankind like cancer, cardiovascular diseases and diabetes directly or indirectly involve the role of peroxidases. So the status of peroxidase levels may also function as a marker of different diseases. Although many types of diseases in human beings have a strong correlation with tissue specific peroxidases, the clear role of these oxido-reductases is not yet fully understood. Here we are focusing on the role of peroxidases in relations with different diseases occurring due to oxidative stress.
\end{abstract}

Keywords: eosinophil peroxidase, glutathione peroxidase, human diseases, lactoperoxidase, myeloperoxidase, oxidative stress, salivary/oral peroxidase, thyroid peroxidase

\section{Introduction}

Reactive oxygen species (ROS) are constantly generated in various metabolic activities of all aerobic organisms. These ROS are involved in various normal cellular activities but any imbalance in their production leads to oxidative stress (Burdon, 1995; Droge, 2002). The oxidative stress results in elevated oxyradical generation, protein and other macromolecular oxidation, and finally leads to different diseases (Everse \& Coates, 2005).

Recent research shows that controlled level of ROS have biochemical importance as well; as they are used in intracellular signalling, regulate several kinases, transcriptional factors and the cell death machinery (Nomura et al., 2001). ROS have a major role in cytotoxicity and apoptosis (Camandola et al., 2000) and contribute to aging and many human diseases (Lenaz, 1998). These ROS can damage almost all biomolecules if their amount exceeds beyond a normal level (Fridell et al., 2005).

To combat ROS generated complications, cells have developed in parallel a complex enzymatic and non-enzymatic antioxidant defence systems among which peroxidases play an important role (Caremel-Harel \& Storz, 2000; Rowinski et al., 2013).

\section{Peroxidases}

Peroxidases belong to a large family of isoenzymes present in almost all living organisms. These are generally heme containing enzymes ranging in $\mathrm{Mw}$ from 35-100 Kd (O'Brien, 2000). Mammalian peroxidases are much larger proteins (576-738 amino acids) than the plant counterparts. Peroxidases exist as monomers, dimmers or 
tetramers and their gene locations also vary among different chromosomes. For example, Glutathione peroxidase $4(\mathrm{GPx} 4)$ is a monomer (gene locus on chromosome 19 p13.3), Eosinophil peroxidase (EPO) exists as a dimer (gene locus on chromosomes 17), while Gluatathione peroxidase 1 (GPx1) is a homotetramer (gene locus on chromosome 3 p21.3) (O’Brien, 2000; Brigelius-Flohe \& Maiorino, 2013).

In mammals, peroxidases have some organ, tissue, cellular and sub-cellular specific distribution patterns, performing some specific functions. These peroxidases include, glutathione peroxidase (GPx), myeloperoxidase (MPO), eosinophil peroxidase (EPO), uterine peroxidase, lactoperoxidase (LPO), salivary peroxidase (SPO) and thyroid peroxidase (TPO) (Klebanoff, 2005). These peroxidases play an important role in wide metabolic activities and are directly or indirectly involved in various diseases (Cheng et al., 2008).

Peroxidases generally use $\mathrm{H}_{2} \mathrm{O}_{2}$ as one of the substrates and participate in oxidizing drug and xenobiotic detoxification, innate immunity, hormone biosynthesis and the pathogenesis of inflammatory diseases (Lubos et al., 2011). Even though peroxidases perform a great role in protective mechanisms but still some peroxidases can also lead to some deleterious reactions like co-oxidation of endogenous substrates, drugs and xenobiotics which lead to lipoprotein oxidation, carcinogenesis and liver necrosis. So nowadays even variety of inhibitors are also used against different types of tissue specific peroxidases to treat various types of diseases (Schulz et al., 2012).

\subsection{Reaction Mechanism of Peroxidases}

Generally peroxidases are heme containing oxido-reductases, and after binding substrates undergo series of redox reactions. The heme group of native peroxidase is usually feriprotoporphyrin IX, containing four pyrrole rings to Fe (III). On proximal side, the fifth coordination position is occupied by the imidazole side chain of histidine residue. The sixth coordination is used in the reaction progression (Wirstam et al., 1999). Different human peroxidases have varied substrate specificities, redox properties and kinetics of interconversion of redox intermediates, even though they share similar functional or structural homology (Furtmuller et al., 2006). The majority of the reactions of peroxidases involve interaction with an oxidants such as $\mathrm{H}_{2} \mathrm{O}_{2}$, alkyl hydroperoxides, peroxybenzoic acids, as well as $\mathrm{OCl}^{-}, \mathrm{OBr}^{-}, \mathrm{ClO}_{2}{ }^{-}, \mathrm{BrO}_{3}{ }^{-}, \mathrm{IO}_{4}^{-}, m$-nitrobenzoic acid etc.

Depending on the substrate availability and the type of peroxidase, these oxido-reductases either go through peroxidase cycle or halogenation cycle (Flemmig et al., 2014) (Figure 1).

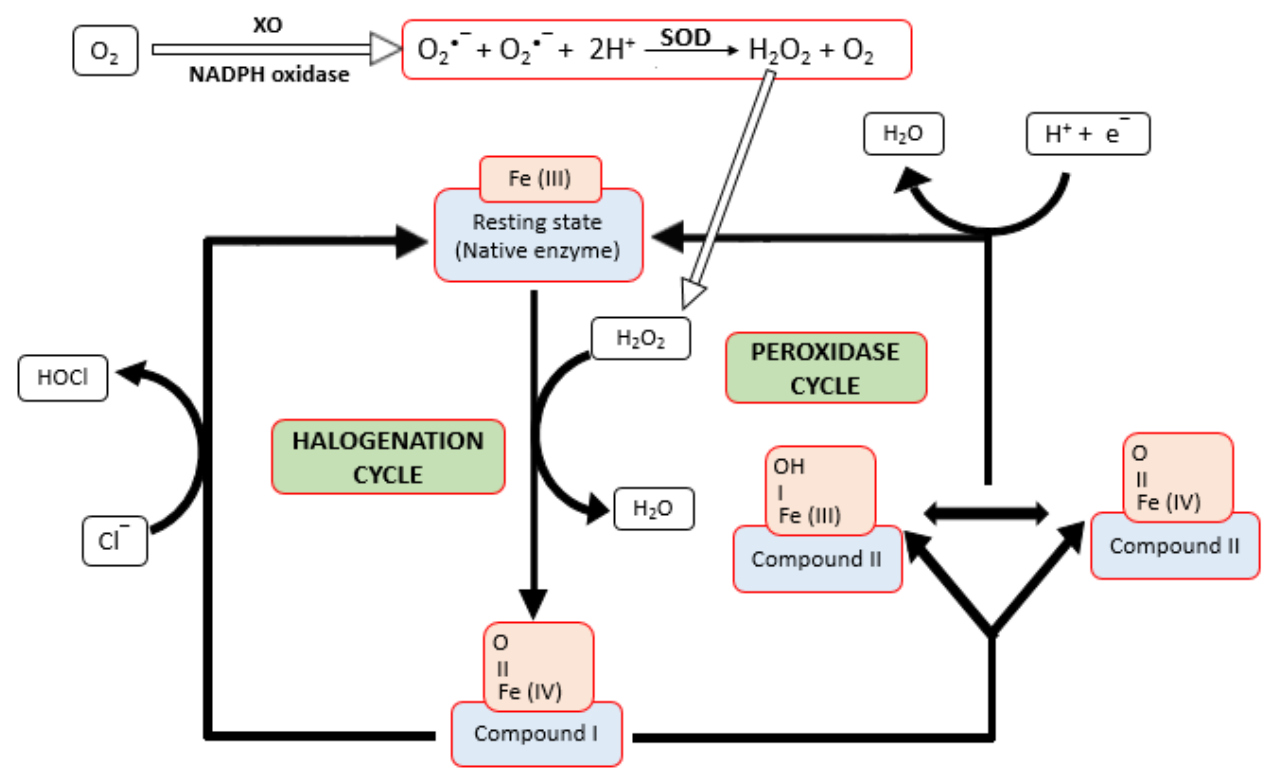

Figure 1. Fundamental steps of the catalytic cycle of heme peroxidases. Free radicals $\mathrm{O}_{2}^{--}$(hydroxyl radical) is generated by the action of xanthine oxidase (XO) or NADPH oxidase and $\mathrm{H}_{2} \mathrm{O}_{2}$ is formed from these free radicals by superoxide dismutase (SOD)

Several intermediate forms of peroxidases (compound I and compound II) are formed during these reaction cycle paths (Paumann-Page et al., 2013). Both peroxidase and halogenation cycle starts by reaction of the Fe (III) form of the peroxidase (native enzyme) with hydrogen peroxide to form compound I, which contains two oxidizing equivalents more than the resting enzyme (Wirstam et al., 1999; O’Brien 2000; Kettle et al., 2011). 
All heme peroxidases can oxidize halide ions via halogenation cycle through compound I and generally the ease of oxidation of these ions is as: $\mathrm{I}^{-}>\mathrm{Br}^{-}>\mathrm{Cl}^{-}\left(\mathrm{O}^{\prime}\right.$ Brien, 2000). In peroxidase cycle, compound $\mathrm{I}$ is reduced by two successive one-electron step via compound II. In these one-electron oxidation reactions, numerous substrates are oxidized to their corresponding radicals (Furtmuller et al., 2006).

\subsection{Regulation of Peroxidases}

Several diverse factors are responsible for the regulation of peroxidase activity in a cell. Different types of pathogens like bacteria also induce or suppress peroxidase mRNA levels in different organisms (Zhang et al., 2011). Exposure of heavy metals like $\mathrm{Cd}, \mathrm{Cu}, \mathrm{Cr}$ and $\mathrm{Ni}$ either activate or inhibit peroxidase level (Woo et al., 2009). Selenium level regulates the GPx mRNA and its enzyme activity as it is a part of selenocysteine, an important amino acid found in glutathione peroxidases.

During different diseases, increased or decreased expressions of peroxidases have been defined by several mechanisms, but these mechanisms do not satisfactorily explain the role of these enzymes. For example, some tumour cells have been observed to have lower GPx activity because tumour cells deplete the level of glutathione (GSH). This GSH depletion stimulates the tyrosinase activity (del Marmol et al., 1993). Tyrosinase activation in melanoma cells leads to higher pigmentation, which is a compensatory mechanism for the decreased GPx levels as melanin is also considered a scavenger of active oxygen species (Ridnour et al., 2004).

One of the characteristics of ROS is role in oxidative DNA mutations and such DNA mutations can be prevented by several peroxidases which counteract the production of proinflammatory mediators such as prostaglandins and leukotrienes (Flohe \& Brigelius-Flohe, 2006). So different Inflammatory processes in several diseases like cancer, diabetes, asthma, pneumonia result in up-regulation of some specific peroxidases and prevent initiation phase of these diseases at least.

\section{Role of Different Peroxidases in Human Diseases}

Peroxidases are directly or indirectly correlated with some leading diseases of mankind like Parkinson's disease, coronary artery disease (CAD) (Tang et al., 2008), convulsive diseases (Kawakami et al., 2006), periodontal diseases (Patel et al., 2009), skin diseases and cancer (Brigelius-Flohe \& Kipp, 2009). These diseases can also arise due to several different agents like auto-antibodies, flavonoids and thiocyanates. which involve the metabolic pathways of peroxidase action.

The role of major types of peroxidases in human beings and their correlation with different types of diseases is described here.

\subsection{Glutathione Peroxidases}

Glutathione peroxidases (GPx) are heme thiol peroxidases, comprising a family of eight isoenzymes (GPx1-8) with diverse functions besides catalysing reduction of $\mathrm{H}_{2} \mathrm{O}_{2}$ or organic hydroperoxides to water or alcohols (Ursini et al., 1995). GPx family members have varied distribution in human body between different organs, tissues or cellular compartments (Khan \& Gowder, 2014).

GPx 1 is the most abundant among GPx family proteins as it is found in erythrocytes and other tissues. It protects these cells from harmful effects of $\mathrm{H}_{2} \mathrm{O}_{2}$ produced by coupled oxidation of different hydrogen donors with oxyhemoglobin (Brigellius-Flohe \& Kipp, 2009). Different types of diseases have been reported due to either over or under-expression of GPx1 like hyperglycemia, hyperbilirubinemia and obesity (McClung et al., 2004).

GPx2 is mainly expressed in gastrointestinal tract and it is produced more during squamous cell carcinoma (Serewko et al., 2002), and colorectal cancer (Chiu, 2005). GPx3 has also been found to be expressed more during chemotherapy of head and neck cancer patients (Chen et al., 2011), diabetic and obese subjects (Baez-Duarte et al., 2012). Besides this, down-regulation of this enzyme occurs during endometrial adenocarcinoma (Falck et al., 2010).

GPx4 lowers hydroperoxide level in cells and is responsible for reducing many types of inflammations (Papp et al., 2007), sperm maturation and motility (Kriska et al., 2008). GPx5 has more specific location in epididymis playing a great role in fertility and helps proper embryonic development (Zhang et al., 2008). Little knowledge is still available about the GPx6. GPx7 and GPx8 play a role in protein disulphide isomerization, so involved in folding of different types of proteins (Bosello-Travain et al., 2013).

\subsubsection{Regulation of Glutathione Peroxidases Enzyme Level}

Selenium level directly regulates the quantity of different forms of GPx proteins. At low selenium level, the GPx 1 mRNA degrades faster in cytoplasm as compared to GPx2 and GPx4 mRNA (Brigelius-Flohe and Maiorino, 2013). Selenocysteine, an unusual amino acid is encoded by UGA codon present in GPx mRNA 
(Chambers et al., 1986). It is usually meant for stop translation for the other proteins, but a new mechanism has been evolved in GPx mRNA, where it codes for Selenocysteine. Sec-tRNA is produced from serine bound to tRNA ${ }^{\text {(ser)sec }}$ by selenophosphate synthatase-2 (SPS2), selenophosphate and Sec synthase (Xu et al., 2007).

Several macromolecular complexes, proteins and enzymes are involved for this differentiation between stop to Selenocysteine translation signal. These complexes include a specific Selenocysteine containing tRNA $\left(\mathrm{t}-\mathrm{RNA}^{\text {(ser)sec }}\right)$, the second requirement is a stem loop structure formation in the 3' untranslated region (3'UTR) of GPx mRNA. This stem loop is called Selenocysteine insertion sequence (SECIS) (Shen et al., 1993). This SECIS recruits a chain of specific tRNA ${ }^{\text {(ser)sec }}$ binding proteins and form a complex called Sec incorporation complex. These proteins include SECIS binding protein 2 (SBP2), Sec elongation factor $\left(\mathrm{EF}^{\mathrm{Sec}}\right)$, SEC P43, ribosomal L30 and nuclease sensitivity element binding protein 1 (NSEP1) (Chavatte et al., 2005; Shen et al., 2006; Donowan et al., 2008) (Figure 2).

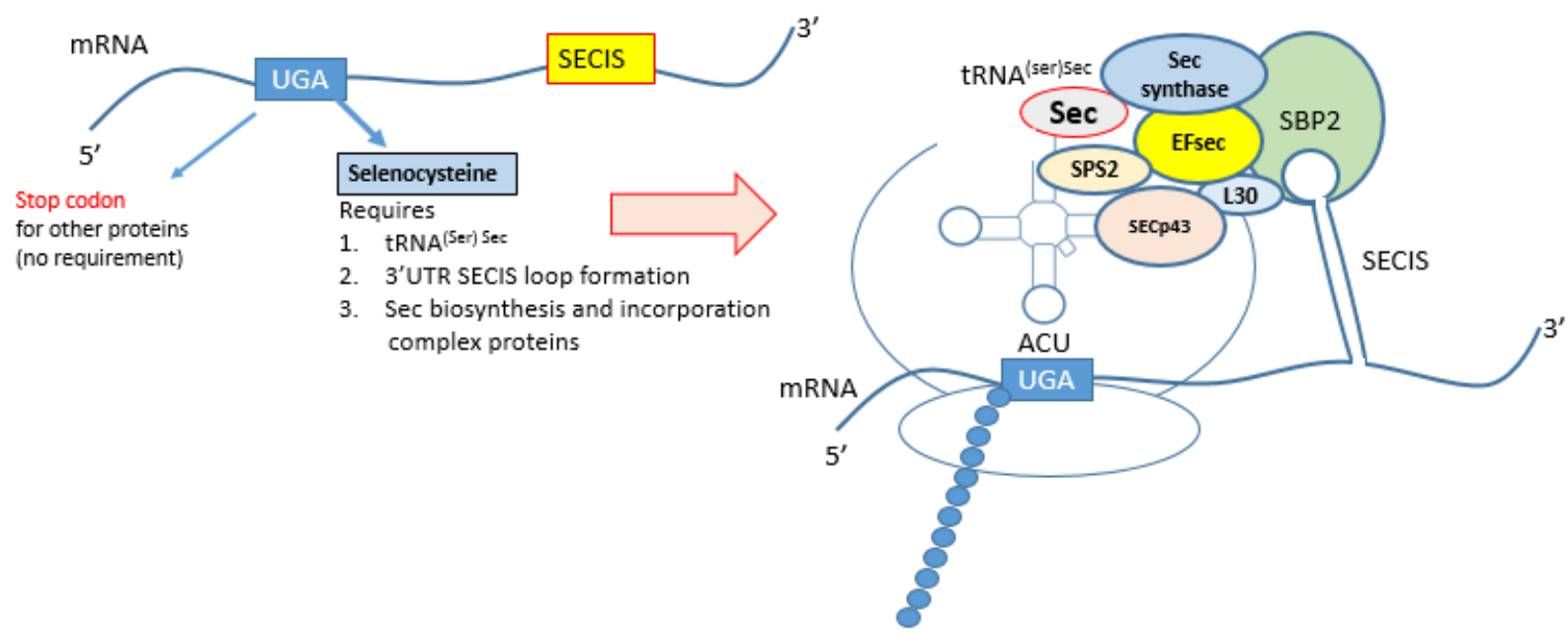

Figure 2. Selenocysteine containing Glutathione peroxidase biosynthesis model

3'UTR is the most important to determine the type of GPx form to be translated. Eukaryotic initiation factor 4a3 (eIF4a3) interacts with a subset of selenoprotein mRNA and prevents binding of SBP2 and thus stops translation (Budiman et al., 2009). This elongation factor (eIF4a3) is induced in selenium deficiency and binds to type-1 SECIS elements, which is SECIS in GPx1 but not in GPx4. So in selenium deficiency, Sec incorporation complex is not formed and GPx1 mRNA does not get translated. Another factor which discriminates between selenoprotein-specific SECIS is nucleolin. Nucleolin has been shown to bind to GPx1 SECIS and thus might link GPx 1 mRNA to other proteins of the selenoprotein translation complex (Wu et al., 2000).

\subsection{Thyroid Peroxidase}

Thyroid peroxidase also called as thyroperoxidase (TPO) is mainly expressed in thyroid organs. It is a large transmembrane glycoprotein with covalently linked haem, present in cells on the apical membrane (Gardas et al., 1999). In thyroid glands; iodination of tyrosine for the biosynthesis of thyroid hormone is an important key reaction catalyzed by TPO. TPO also catalyzes the formation of thyroglobulin mono-iodotyrosine and thyroglobulin di-iodotyrosine to form thyroglobulin bound thyroxine (Cheng et al., 2008). A direct correlation has been observed between thyroid disease and TPO (Bakker et al., 2000) as the genetic deficiency of this enzyme causes congenital hypothyroidism (Roos et al., 2010).

Patients with complications of Grave's hyperthyroidism (Robert \& Raeburn, 2009), postpartum thyroiditis (Stagnaro-Green, 2004), and Hashimoto's thyroiditis (Roberts \& Ladenson, 2004) have different levels of autoantibodies present against TPO which represent a hallmark of autoimmune thyroid diseases (Prummel, 2005). Further, in euthyroid subjects, thyrotropin (TSH) is associated with autoantibody (TPOAb) titers (Strieder et al., 2003). Lymphocytic infiltration of TPO antibodies during early stages of development can be seen as predictor for the development of hypothyroidism in future (Scofield, 2004). One of the important complications during pregnancy can be hypothyroidism, so measurement of TPO autoantibodies is recommended strongly. If first trimester of pregnancy shows highest levels of TPO autoantibodies, it can lead to development of hypothyroidism in the postpartum period (Chadha \& Goel, 2009). 
Thyroid peroxidase is also inactivated by consumption of a number of diets, rich in flavinoids, so such foods can lead to goitre or even thyroid cancer formation. So Infants who receive foods containing excessive soy can show goitre, hypothyroidism and autoimmune thyroid disorders as well (O’Brien, 2000).

\subsection{Lactoperoxidase}

Lactoperoxidase (LPO) is found in wide range of mammalian and human tissues, glands and their secretions. It includes mammary, lachrymal and salivary glands and their secretions like milk, colostrum, tears and saliva (Kussendrager and van Hooijdonk, 2000; Conner et al., 2002; Seifu et al., 2005; Atasever et al., 2013). It contributes to the non-immune host defence system, exerting bacteriostatic and bactericidal activity mainly on Gram negative bacteria (Touch et al., 2004). It also plays an important role against pathogenic microorganisms in intestinal tract of newborn infants (Shin et al., 2000).

Lactoperoxidases have a protective role in respiratory tract. It provides the sterility of different secretions by acting as antibacterial and bacterial clearance agent. For the proper activity of LPO, thiocyanate ( $\left.\mathrm{SCN}^{-}\right)$is a requisite component for its active role, so the defects in $\mathrm{SCN}^{-}$transport channels result in loss of LPO activity. This problem can lead to chronic respiratory infections as commonly seen in cystic fibrosis patients. Furthermore, loss of LPO system can increase the chances of H. pylori, Staphylococci, E. coli and Pseudomonas infections (Boots \& Floris, 2006; Fweja et al., 2008).

LPO has been found in good amount in goat milk and its consumption inhibits the growth of some fungi like Aspergillus, P. chrysogenum, T. species, phytopthora and A. Flavus (Jacob et al., 2000) but increased expression of LPO activity in milk is a direct indication of mastitis, an inflammation of the breast tissue commonly caused by S. epidermidis and Streptococci. Further, orally administered LPO ameliorates induced colitis in mice, with symptoms similar to ulcerative colitis in humans (Shin et al., 2008).

Lactoperoxidase present in the brain (brain peroxidase) play an important role in different metabolic events associated with Parkinson's disease. Role of LPO in Parkinson's disease is confirmed as the cytotoxic activity of this enzyme is fully inhibited by neuroactive compounds like dopamine, reduced glutathione, and L-cysteine (Everse \& Coates, 2004, 2005). Furthermore, LPO present in the skin play an important role in the biosynthesis of melanin in vitro. This function may be relevant to the physiological functions of the melanin pigments in vivo (Garcia-Molina et al., 2005).

\subsection{Salivary/Oral Peroxidase}

Different harmful microorganisms enter the human body through the oral passage regularly. These bacteria are killed by the first line of defence system present in saliva, which includes salivary peroxidase (SPO) as the major peroxidase. Oral peroxidases OPO are composed of salivary peroxidase $(80 \%)$ and MPO (20\%) (Pruitt et al., 1990; Nagler et al., 2002). SPO inhibits both Gram-positive and Gram-negative oral and non-oral bacteria. In addition to this, SPO shows antiviral (Yamamoto et al., 1991; Chase \& Klebanove, 1992; Mikola et al., 1995), and antifungal (MacCarthy \& Dahl, 1989; Lenander-Lumikari, 1992) activities.

Salivary peroxidase also forms an oral antioxidant system especially against the attack of free radicals produced by cigarette smoke which can lead to oral cancer. It has been observed that smoking even a single cigarette results in a sharp drop of OPO activity. This results in increased carbonylation of the salivary proteins an indication of the oxidative damage to the proteins. Heavy smokers have less OPO activity against the deleterious effects of thiocyanate ions and hydroxyl radicals produced by higher $\mathrm{H}_{2} \mathrm{O}_{2}$. This makes the way easy for the saliva mediated initiation and progression of oral cancer in heavy smokers (Reznick et al., 2003).

\subsection{Eosinophil Peroxidases}

Eosinophil granulocytes or eosinophils are type of white blood cells actively involved in immune system against multicellular parasites and other infections. Eosinophil granules contain a good quantity of eosinophil peroxidase (EPO) (40\%) which performs a vast majority of functions during different diseased states. EPO is actively involved in $\mathrm{Cl}^{-}, \mathrm{Br}^{-}, \mathrm{I}^{-}$and $\mathrm{SCN}^{-}$oxidation. During infectious state eosinophils are responsible for killing multicellular parasites such as nematode worms involved in filariasis and also certain bacteria such as $M$. tuberculosis. Furthermore, elevation or activation of eosinophils leads to the release of granular proteins linked with variety of inflammatory diseases including allergic diseases of the skin (e.g., atopic dermatitis (Leiferman, 1989)), the lungs (Lacoste et al., 1993) and gastrointestinal tract (e.g., eosinophil esophagitis (Rothenberg et al., 2001)). In addition to this, EPO is also involved in autoimmune neurologic disorders (e.g., multiple sclerosis; (Correale \& Fiol, 2004) cancer (Samoszuk, 1997) transplantation rejection and infection with parasitic (Klion \& Nutman, 2004) and fungal agents (Schubert, 2006).

Direct evidence of the role of EPO in the pathogenesis is scanty, despite all the above described eosinophil 
related diseases. Development of EPO knockout mouse line (Denzler et al., 2001) has greatly aided the analysis of the role of EPO in the pathogenesis of different diseases.

\subsection{Myeloperoxidase}

Myeloperoxidase (MPO) is packed inside the cytoplasmic azurophilic granules of neutrophils and is involved in unspecific immune defence system responsible for microbicidal activity (Kajer et al., 2014). MPO catalyzes lipid peroxidation via tyrosyl radical formation (Savenkova et al., 1994) and this leads to generation of other products which cause lipoprotein oxidation (Daugherty et al., 1994). Oxidation of lipoproteins like HDL contributes to atherosclerosis by counteracting HDL anti-atherogenic effects (Bergt et al., 2004; Zheng et al., 2004).

MPO has been strongly implicated in other disease like rheumatoid arthritis, atherosclerosis and lung cancer (Hoy et al., 2002). It has been reported that some chest pain patients show significant MPO levels and MPO oxidation products have been observed in brains of patients diagnosed with Alzheimer's disease and multiple sclerosis (Nagra et al., 1997; Reynolds et al., 1999; Crawford et al., 2000; Green et al., 2004). MPO is also released from polymorphonuclear neutrophils and monocytes in acute coronary syndrome after activation and so listed as risk marker in such diseases (Mocatta et al., 2007; Ndrepepa et al., 2008).

Recent research shows that MPO is an emerging biomarker to assess cardiovascular diseases (CVD) and endothelial dysfunction in vivo (Eiserich et al., 2002; Brennan \& Hazen, 2003) as human subjects with significantly lower risks of CVD were found to have less MPO activity and vice-versa (Zhang et al., 2001). Even though this enzyme has been used as a risk marker in this syndrome (Morrow et al., 2007), its proper role in such patients is not yet well defined. There is also a strong association between carotid atherosclerosis and the MPO in patients whose HDL cholesterol levels are less than desirable value (Exner et al., 2006).

It has also been observed that inherited MPO defects can lead to impaired fungicidal activity which can lead to candidiasis (Cheng et al., 2008). Furthermore, MPO leads to the development of atheroma and plaque rupture as it generates reactive oxidants and radicals as well.

\section{Other Peroxidases}

Several other peroxidases and related diseases have been identified, but are less characterized. These peroxidases have also some tissue specific distribution and functions. These include vascular peroxidase, uterine peroxidase, prostaglandin $\mathrm{H} 1 / 2$ synthase, etc. Uterine peroxidase plays an important role in oestrogen-induced uterine hyperaemia and uterine weight by conversion of oestrogen to their catechol forms (Farley et al., 1992). Several eye diseases like cataract and macular degeneration may be related with the oxidative mechanisms also, as few studies have shown that high levels of GPx are associated with age related macular degeneration (Delcourt et al., 1999). These peroxidases have more or less common mechanism of action with other common peroxidases and promising research is going on in understanding their proper roles.

\section{Conclusion}

Different types of oxyradicals once considered as harmful products are now know to perform some essential cellular functions. But any imbalance in their production leads to varied diseases, so putting forward the burden of this stress on peroxidases as well. Peroxidases play a significant role in antioxidant defense system of living organisms and are actively involved in oxyradical oxidation, hormone biosynthesis, and innate immunity. Different peroxidases have organ, tissue, cellular or sub-cellular specificities and are directly or indirectly involved in various diseases of mankind. During different diseases, the expression of peroxidases either increases or decreases. Several mechanisms have been suggested to explain their varied expressions during diseased states. Even though peroxidases have been used as risk markers in different human diseases but its perfect role is not yet well defined.

\section{References}

Atasever, A., Ozdemir, H., Gulcin, I., \& Kufrevioglu, O. I. (2013). One-step purification of lactoperoxidase from bovine milk by affinity chromatography. Food Chemistry, 136, 864-870. http://dx.doi.org/ 10.1016/j.foodchem.2012.08.072.

Bakker, B., Bikker, H., Vulsma, T., de Randamie, J. S., Wiedijk, B. M., \& De Vijlder, J. J. (2000). Two decades of screening for congenital hypothyroidism in the Netherlands: TPO gene mutations in total iodide organification defects (an update). The Journal of Clinical Endocrinology \& Metabolism, 85, 3708-3712. http://dx.doi.org/10.1210/jc.85.10.3708.

Bergt, C., Pennathur, S., Fu, X., Byun, J., O’Brien, K., McDonald, T. O., ... Heinecke, J. W., (2004).The myeloperoxidase product hypochlorous acid oxidizes HDL in the human artery wall and impairs 
ABCA1-dependent cholesterol transport. Proceedings of National Academy of Science USA, 101, 13032-13037. http://dx.doi.org/10.1073/pnas.0405292101

Boots, J. W., \& Floris. R. (2006). Lactoperoxidase: From catalytic mechanism to practical applications. International Dairy Journal, 16, 1272-1276.

Bosello-Travain, V., Conrad, M., Cozza, G., Negro, A., Quartesan, S., Rossetto, M., ... Maiorino. M. M. (2013). Protein disulfide isomerase and glutathione are alternative substrates in the one Cys catalytic cycle of glutathione peroxidase 7. Biochimica et Biophysica Acta, 1830, 3846-3857. http://dx.doi.org/10.1016/j.bbagen.2013.02.017.

Brennan, M. L., \& Hazen, S. L. (2003). Emerging role of myeloperoxidase and oxidant stress markers in cardio-vascular risk assessment. Current Opinions of Lipidology, 14, 353-359. http://dx.doi.org/ 10.1097/01.mol.0000083762.66245.51

Brigelius-Flohe, R., \& Kipp, A. (2009). Glutathione peroxidases in different stages of carcinogenesis. Biochimica et Biophysica Acta, 170, 1555-1568. http://dx.doi.org/10.1016/j.bbagen.2009.03.006.

Brigelius-Flohe, R., \& Maiorino, M. (2013). Glutathione peroxidase. Biochemica et Biophysica Acta, 1830, 3289-3303. http://dx.doi.org/10.1016/j.bbagen.2012.11.020.

Budiman, M. E., Bubenik, J. L., Miniard, A. C., Middleton, L. M., Gerber, C. A., Cash, A., \& Driscoll, D. M. (2009). Eukaryotic initiation factor $4 \mathrm{a} 3$ is a selenium-regulated RNA-binding protein that selectively inhibits selenocysteine incorporation. Molecular Cell, 35, 479-489. http://dx.org/10.1016/j.molcel. 2009.06.026

Burdon, R. H. (1995). Superoxide and hydrogen peroxide in relation to mammalian cell proliferation. Free Radical Biology \& Medicine, 18, 775-794. http://dx.doi.org/10.1016/0891-5849 (94) 00198-S

Camandola, S., Poli, G., \& Mattson, M. P. (2000). The lipid peroxidation product 4-hydroxy-2,3-nonenal increases AP-1-binding activity through caspase activation in neurons. Journal of Neurochemistry, 74, 159-168. http://dx.doi.org/10.1046/j.1471-4159.2000.0740159.x

Caremel-Harel, O., \& Storz, G., (2000). Roles of the glutathione- and thioredoxin-dependent reduction systems in the Escherichia coli and Saccharomyces cerevisiae responses to oxidative stress. Annual Reviews of Microbiology, 54, 439-461. http://dx.doi.org/10.1146/annurev.micro.54.1.439

Chadha, G., \& Goel, M. (2009). Hypothyroidism in pregnancy. Apollo Medicine, 6, 322-326.

Chambers, I., Frampton, J., Goldfarb, P., Affara, N., McBain, W., \& Harrison, P. R. (1986).The structure of the mouse glutathione peroxidase gene: the selenocysteine in the active site is encoded by the 'termination' codon, TGA. EMBO Journal, 5, 1221-1227.

Chase, M. J., \& Klebanov, S. J. (1992). Viricidal effect of stimulated human mononuclear phagocytes on human immunodeficiency virus type 1. Proc. Natl. Acad. Sci. USA, 89, 5582-5585.

Chavatte, L., Brown, B. A., \& Driscoll, D. M. (2005). Ribosomal protein L30 is a component of the UGA-selenocysteine recoding machinery in eukaryotes. Natural Structure and Molecular Biology, 12, 408-416. http://dx.doi.org/10.1038/nsmb922

Chen, B., Rao, X., House, M. G., Nephew, K. P., Cullen, K. J., \& Guo, Z. (2011). GPx3 promoter hypermethylation is a frequent event in human cancer and is associated with tumorigenesis and chemotherapy response. Cancer Letters, 309, 37-45.

Cheng, G., Salerno, J. C., Cao, Z., Pagano, P. J., \& Lambeth, J. D. (2008). Identification and characterization of VPO1, a new animal heme-containing peroxidase. Free Radical Biology \& Medicine, 45, 1682-1694. http://dx.doi.org/10.1016/j.freeradbiomed. 2008.09.009.

Chiu, S. T., Hsieh, F. J., Chen, S. W., Chen, C. L., Shu, H. F., \& Li, H. (2005). Clinicopathologic correlation of up-regulated genes identified using cDNAmicroarray and real-time reverse transcription-PCR in human colorectal cancer. Cancer Epidemiology Biomarkers Preview, 14, 437-443. http://dx.doi.org/10.1158/1055-9965.EPI-04 0396

Conner, G. E., Salathe, M., \& Forteza, R. (2002). Lactoperoxidase and hydrogen peroxide metabolism in the airway. American Journal of Respiratory and Critical Care Medicine, 66, S57-S61. http://dx.doi.org/10.1164/rccm.2206018

Correale, J., \& Fiol, M. (2004). Activation of humoral immunity and eosinophils in neuromyelitis optica. 
Neurology, 63, 2363-2370. http://dx.doi.org/10.1212/01.WNL. 0000148481.80152.BF

Crawford, F. C., Freeman, M. J., Schinka, J. A., Morris, M. D., Abdullah, L. I., Richards, D., ... Mullan, M. J., (2000). Association between Alzheimer's disease and a functional polymorphism in the myeloperoxidase gene. Experimental Neurology, 167, 456-459. http://dx.doi.org/10.1006/exnr.2000.7560

Daugherty, A., Dunn, J. L., Rateri, D. L., \& Heinecke, J. W. (1994). Myeloperoxidase, a catalyst for lipoprotein oxidation, is expressed in human atherosclerotic lesions. Journal of Clinical Investigations, 94, 437-944. http://dx.doi.org/10.1172/JCI117342

del Marmol, V., Solano, F., Sels, A., Huez, G., Libert, A., Lejeune, F., \& Ghanem, G. (1993). Glutathione depletion increases tyrosinase activity in human melanoma cells. J. Invest. Dermatol., 101, 871-874. http://dx.doi.org/10.1111/1523-1747.ep12371709

Delcourt, C., Cristol, J-P., Leger, C. L., Descomps, B., \& Papoz, L. (1999). Associations of Antioxidant Enzymes with Cataract and Age-related Macular Degeneration, The POLA Study. Ophthalmology, 106, http://dx.doi.org/10.1016/S0161-6420(99)90059-3

Denzler, K. L., Borchers, M. T., Crosby, J. R., Cieslewicz, G., Hines, E. M., Justice, J. P., ... Lee, N. A. (2001). Spectral and kinetic evidence for reaction of superoxide with compound I of myeloperoxidase. Journal of Immunology, 167, 1672-1682. http://dx.doi.org/10.1016/j.freeradbiomed.2011.09.019

Donovan, J., Caban, K., Ranaweera, R., Gonzalez-Flores, J. N., \& Copeland, P. R. (2008). A novel protein domain induces high affinity selenocysteine insertion sequence binding and elongation factor recruitment. Journal of Biological Chemistry, 283, 35129-35139. http://dx.org/10.1074/jbc.M806008200.

Droge, W. (2002). Free radicals in the physiological control of cell function. Physiological Reviews, 82, 47-95. http://dx.doi.org/10.1152/physrev.00018.2001

Eiserich, J. P., Baldus, S., Brennan, M. L., Ma, W., Zhang, C., Tousson, A., ... Freeman, B. A. (2002). Myeloperoxidase, a leukocyte derived vascular NO oxidase. Science, 296, 2391-234. http://dx.doi.org/10.1126/science.1106830

Everse, J., \& Coates, P. W. (2004). The cytotoxic activity of lactoperoxidase: enhancement and Inhibition by neuroactive compounds. Free Radical \& Medicine, 37, 839-849. http://dx.doi.org/10.1016/j.freeradbiomed.2004.06.017

Everse, J., \& Coates, P. W. (2005). Role of peroxidases in Parkinson disease: A hypothesis. Free Radical Biology \& Medicine, 38, 1296-1310. http://dx.doi.org/10.1016/j.freeradbiomed.2005.01.018

Exner, M., Minar, E., Mlekusch, W., Sabeti, S., Amighi, J., Lalouschek, W., ... Schillinger, M. (2006). Myeloperoxidase predicts progression of carotid stenosis in states of low high-density lipoprotein cholesterol. Journal of the American College of Cardiology, 47, 2212-2218. http://dx.doi.org/10.1016/j.jacc.2006.01.067

Falck, E., Karlsson, S., Carlsson, J., Helenius, G., Karlsson, M., \& Klinga-Levan, K. (2010). Loss of glutathione peroxidase 3 expression is correlated with epigenetic mechanisms in endometrial adenocarcinoma. Cancer Cell Int., 10, 46.

Farley, D. B., Ford, S. P., \& Rosazza, J. P. N. (1992). Increase in uterine peroxidase activity in the rat uterus during oestrogen hyperaemia. Journal of Reproduction \& Fertility, 95, 551-558. http://dx.doi.org/10.1530/jrf.0.0950551

Flemmig, J., Remmler, J., Röhring, F., \& Arnhold. J. (2014). (-)-Epicatechin regenerates the chlorinating activity of myeloperoxidase in vitro and in neutrophil granulocytes. Journal of Inorganic Biochemistry, 130, 84-91. http://dx.doi.org/10.1016/j.jinorgbio.2013.10.002

Flohe, L., \& Brigelius-Flohe, R. (2006). Selenoproteins of the glutathione system. In D. L. Hatfield (Ed.), Selenium. Its Molecular Biology and Role in Human Health (2nd ed., pp. 161-172), Boston, Dordrecht, London: Kluwer Academic Publishers.

Fridell, Y.-W. C., Sanchez-Blanco, A., Silvia, B. A., \& Helfand, S. L. (2005). Targeted expression of the human uncoupling protein 2 (Hucp2) to adult neurons extends life span in the fly. Cell Metabolism, 1, 145-152. http://dx.doi.org/10.1016/j.cmet.2005.01.005

Furtmuller, P. G., Zederbauer, M., Jantschko, W., Helm, J., Bogner, M., Jakopitsch, C., \& Obinger, C. (2006). Active site structure and catalytic mechanisms of human peroxidases. Archives of Biochemistry and Biophysics, 445, 199-213. http://dx.doi.org/10.1016/j.abb.2005.09.017 
Fweja, L. W. T., Lewis, M. J., \& Grandison, A. S. (2008). Challenge testing the lactoperoxidase system against a range of bacteria using different activation agents. Journal of Dairy Science, 91, 2566-2574. http://dx.doi.org/10.3168/jds.2007-0322.

Garcia-Molina, F., Fenoll, L. G., Morote, J. C., García-Ruiz, P. A., Rodríguez-Lopez, J. N., García-Canovas, F., \& Tudela, J. (2005). Opposite effects of peroxidase in the initial stages of tyrosinase-catalysed melanin biosynthesis biosynthesis. The International Journal of Biochemistry \& Cell Biology, 37, 1179-1196. http://dx.doi.org/10.1016/j.biocel.2004.11.009

Gardas, A., Sutton, B. J., Piotrowska, U., Pasieka, Z., Barnett, P. S., Huang, G., ... Banga, J. P. (1999). Distinct immunological and biochemical properties of thyroid peroxidase purified from human thyroid glands and recombinant protein produced in insect cells. Biochimica et Biophysica Acta, 1433, 229-239. http://dx.doi.org/10.1016/S0167-4838(99)00128-4

Green, P. S., Mendez, A. J., Jacob, J. S., Crowley, J. R., Growdon, W., Hyman, B. T., \& Heinecke, J. W., (2004). Neuronal expression of myeloperoxidase is increased in Alzheimer's disease. Journal of Neurochemistry, 90, 724-733. http://dx.doi.org/10.1111/j.1471-4159.2004.02527.x

Hoy, A., Leininger-Muller, B., Kutter, D., Siest, G., \& Visvikis S. (2002). Growing significance of myeloperoxidase in non-infectious diseases. Clinical Chemistry \& Laboratory Medicine, 40, 2-8. http://dx.doi.org/10.1515/CCLM.2002.002

Jacob, B. M., Anthony, K. E., Sreekumar, B., \& Haridas, M. (2000). Thiocyanate mediated antifungal and antibacterial property of goat milk. Life Sciences Including Pharmacology Letter, 66, 2433-2439. http://dx.doi.org/10.1016/S0024-3205(00)80003-X

Kajer, T. B., Fairfull-Smith, K. E., Yamasaki, T., Yamada, K., Fu, S., Bottle, S. E., ... Davies, M. J., (2014). Inhibition of myeloperoxidase- and neutrophil-mediated oxidant production by tetraethyl and tetramethyl nitroxides. Free Radical Biology and Medicine, 70, 96-105. http://dx.doi.org/10.1016/ j.freeradbiomed.2014.02.011

Kawakami, Y., Monobe, M., Kuwabara, K., Fujita, T., Maeda, M., Fujino, O., ... Fukunaga, Y. (2006). A comparative study of nitric oxide, glutathione, and glutathione peroxidase activities in cerebrospinal fluid from children with convulsive diseases/children with aseptic meningitis. Brain and Development, 28, 243-246. http://dx.doi.org/10.1016/j.braindev.2005.08.010

Kettle, A. J., Maroz, A., Woodroffe, G., Winterbourn, C. C., \& Anderson, R. F. (2011). Spectral and kinetic evidence for reaction of superoxide with compound I of myeloperoxidase. Free Radical Biology \& Medicine, 51, 2190-2194.

Khan, A. A., \& Gowder, S. J. T. (2014). Glutathione peroxidase: A potential marker for the most common diseases and disorders. Recent Patents on Biomarkers, 4, 1-10. http://dx.doi.org/10.2174 $/ 2210309004666140222002755$

Klebanoff, S. J. (2005). Myeloperoxidase: friend and foe. Journal of Leukocyte Biology, 77, 598-625. http://dx.doi.org/10.1189/jlb.1204697

Klion, A. D., \& Nutman, T. B. (2004). The role of eosinophils in host defense against helminth parasites. Journal of Allergy \& Clinical Immunology, 113, 30-37. http://dx.doi.org/10.1016/j.jaci.2003.10.050

Kriska, T., Levchenko, V. V., Chu, F-F., Esworthy, R. S., \& Girotti, A.W. (2008). Novel enrichment of tumor cell transfectants expressing high levels of type 4 glutathione peroxidase using $7 \alpha$-hydroperoxycholesterol as a selection agent. Free Radical Biology \& Medicine, 45, 700-707.

Kussendrager, K. D., \& van Hooijdank, A. C. M. (2000). Lactoperoxidase: physicochemical properties, occurrence, mechanism of action and applications. British Journal of Nutrition, 84, 19-25.

Lacoste, J. Y., Bousquet, J., Chanez, P., Van Vyve, T., Simony-Lafontaine, J., Lequeu, N., .. Michel, F. B. (1993). Eosinophilic and neutrophilic inflammation in asthma, chronic bronchitis, and chronic obstructive pulmonary disease. Journal of Allergy \& Clinical Immunology, 92, 537-548. http://dx.doi.org/10.1016/0091-6749(93)90078-T

Leiferman, K. M. (1989). Eosinophils in atopic dermatitis. Allergy, 9, 20-26.

Lenander-Lumikari, M. (1992). Inhibition of Candida albicans by the peroxidase $/ \mathrm{SCN}^{-} / \mathrm{H}_{2} \mathrm{O}_{2}$ system. Oral Microbiology and Immunology, 7, 315-320. http://dx.doi.org/10.1111/j.1399-302X.1992.tb00595.x

Lenaz, G. (1998). Role of mitochondria in oxidative stress and ageing. Biochimica Biophysica Acta, 1366, 53-67. 
Lubos, E., Loscalzo, J., \& Handy, D. E. (2011). Glutathione peroxidase-1 in health and disease: from molecular mechanisms to therapeutic opportunities. Antioxidant Redox Signal., 15, 1957-1997. http://dx.doi.org/10.1089/ars.2010.3586

MacCarthy, K. G., \& Dahl, M. V. (1989). Inhibition of Growth of Trichophyton rubrum by the Myeloperoxidase-Hydrogen Peroxide-Chloride System. Journal of Investigative Dermatology, 92, 639-641. http://dx.doi.org/10.1111/1523-1747.ep12712205

McClung, J. P., Roneker, C. A., Mu, W., Lisk, D. J., Langlais, P., Liu, F., \& Lei, X. G. (2004). Development of insulin resistance and obesity in mice overexpressing cellular glutathione peroxidase. Proc. Natl. Acad. Sci. U. S. A., 101, 8852-8857. http://dx.doi.org/10.1073/pnas.0308096101

Mikola, H., Waris, M., \& Tenovuo, J. (1995). Inhibition of herpes simplex virus type 1, respiratory syncytial virus and echovirus type 11 by peroxidase-generated hypothiocyanite. Antiviral Research, 26, 161-171.

Mocatta, T. J., Pilbrow, A. P., Cameron, V. A., Senthilmohan, R., Frampton, C. M., Richards, A. M., \& Winterbourn, C. C. (2007). Plasma concentrations of myeloperoxidase predict mortality after myocardial infarction. Journal of American College of Cardiology, 49, 1993-2000. http://dx.doi.org/ 10.1016/j.jacc.2007.02.040

Morrow, D. A., Cannon, C. P., Jesse R, L., Newby, L. K., Jan Ravkilde, Storrow, A. B., ... Christenson, R. A. (2007). National Academy of Clinical Biochemistry Laboratory Medicine Practice Guidelines: clinical characteristics and utilization of biochemical markers in acute coronary syndromes. Clinical Chemistry, 53, 552-74. http://dx.doi.org/10.1373/clinchem.2006.084194

Nagler, R. M., Klein, I., Zarzhevsky, N., Drigues, N., \& Reznick, A. Z. (2002). Characterization of the differentiated antioxidant profile of human saliva. Free Radical Biology and Medicine, 32, 268-277. http://dx.doi.org/10.1016/S0891-5849(01)00806-1

Nagra, R. M., Becher, B., Tourtellotte, W. W., Antel, J. P., Gold, D., Paladino, T., ... Reynolds, W. F., (1997). Immunohistochemical and genetic evidence of Myeloperoxidase involvement in multiple sclerosis. Journal of Neuroimmunology, 78, 97-107. http://dx.doi.org/10.1016/S0165-5728(97)00089-1

Ndrepepa, G., Braun, S., Mehilli, J., von Beckerath, N., Schomig, A., \& Kastrati, A. (2008). Myeloperoxidase level in patients with stable coronary artery disease and acute coronary syndromes. European Journal of Clinical Investigations, 38, 90-96. http://dx.doi.org/10.1111/j.13652362. 2007.01908.x

Nomura, K., Imai, H., Koumura, T., \& Nakagawa, Y. (2001) Involvement of mitochondrial phospholipid hydroperoxide glutathione peroxidase as an antiapoptotic factor. Biological Signals \& Receptors, 10, 81-92. http://dx.doi.org/10.1159/000046877

O’Brien, P. J. (2000). Peroxidase. Chemico-Biological Interactions, 129, 113-139. http://dx.doi.org/10.1016/S0009-2797(00)00201-5

Papp, L. V., Lu, J., Holmgren, A., \& Khanna, K. K. (2007). From selenium to selenoproteins: synthesis, identity, and their role in human health. Antioxidand Redox Signal, 9, 775-806.

Patel, S. P., Pradeep, A. R., \& Chowdhry, S. (2009). Crevicular fluid levels of plasma glutathione peroxidase (eGPx) in periodontal health and disease. Archives of Oral Biology, 54, 543-548. http://dx.doi.org/10.1016/j.archoralbio.2009.02.002

Paumann-Page, M., Furtmüller, P. G., Hofbauer, S., Paton, L. N., Obinger, C., \& Kettle, A. J. (2013). Inactivation of human myeloperoxidase by hydrogen peroxide. Archives of Biochemistry and Biophysics, 539, 51-62. http://dx.doi.org/10.1016/j.abb.2013.09.004

Pruitt, K. M., Kamau, D. N., Miller, K., Mansson-Rahemtulla, B., \& Rahemtulla, F. (1990). Quantitative, standardized assays for determining the concentrations of bovine lactoperoxidase, human salivary peroxidase, and human myeloperoxidase. Analytical Biochemistry, 191, 278-286. http://dx.doi.org/10.1016/0003-2697(90)90220-4

Prummel, M. F. (2005). Thyroid peroxidase autoantibodies in euthyroid subjects. Best Practice \& Research Clinical Endocrinology \& Metabolism, 19, 1-15. http://dx.doi.org/ 10.1016/j.beem.2004.11.003

Reynolds, W. F., Rhees, J., Maciejewski, D., Paladino, T., Sieburg, H., Maki, R. A., \& Masliah, E. (1999). Myeloperoxidase polymorphism is associated with gender specific risk for Alzheimer's disease. Experimental Neurology, 155, 31-41. http://dx.doi.org/10.1006/exnr.1998.6977

Reznick, A. Z., Klein, I., Eiserich, J. P., Cross, C. E., \& Nagler, R. M. (2003). Inhibition of oral peroxidase 
activity by cigarette smoke: In vivo and in vitro studies. Free Radical Biology \& Medicine, 34, 377-384. http://dx.doi.org/10.1016/S0891-5849(02)01297-2

Ridnour, L. A., Oberley, T. D., \& Oberley, L. W. (2004) Tumor suppressive effects of MnSOD overexpression may involve imbalance in peroxide generation versus peroxide removal. Antioxidant Redox Signal, 6, 501-512. http://dx.doi.org/10.1089/152308604773934260

Robert, C., McIntyre, Jr., \& Raeburn, C. D. (2009). Hyperthyroidism. Chapter 58. Abernathy's surgical secrets (6th ed., pp. 288-291).

Roberts, C. G., \& Ladenson, P. W. (2004). Hypothyroidism. Lancet, 363, 793-803. http://dx.doi.org/10.1016/S01406736(04)15696-1

Roos, A., Links, T. P., de Jong-van den Berg, L. T., Gans, R. O., Wolffenbuttel, B. H., \& Bakker. S. J. (2010). Thyroid peroxidase antibodies, levels of thyroid stimulating hormone and development of hypothyroidism in euthyroid subjects. European Journal of Internal Medicine, 21, 555-559. http://dx.doi.org/10.1016/j.ejim.2010.09.001.

Rothenberg, M. E., Mishra, A., Collins, M. H., \& Putnam, P. E. (2001). Pathogenesis and clinical features of eosinophilic esophagitis. Journal of Allergy \& Clinical Immunology, 108, 891-894. http://dx.doi.org/10.1067/mai.2001.120095

Rowinski, R., Kozakiewicz, M., Kedziora-Kornatowska, K., Hubner-Wozniak, E., \& Jozef-Kedziora, J. (2013). Markers of oxidative stress and erythrocyte antioxidant enzyme activity in older men and women with differing physical activity. Experimental Gerontology, 48, 1141-1146. http://dx.doi.org/10.1016/j.exger.2013.07.010

Samoszuk, M. (1997). Eosinophils and human cancer. Histology \& Histopathology, 12, 807-812. PMID: 9225164

Savenkova, M. L., Mueller, D. M., \& Heinecke, J. W. (1994). Tyrosyl radical generated by myeloperoxidase is a physiological catalyst for the initiation of lipid peroxidation in low density lipoprotein. Journal of Biological Chemistry, 1994, 269, 20394-20400. PMID: 8051134

Schubert, M.S. (2006). Allergic fungal sinusitis. Clinical Reviews in Allergy \& Immunology, 30, 205-216. http://dx.doi.org/10.1385/CRIAI:30:3:205

Schulz, R., Emmrich, T., Lemmerhirt, H., Leffler, U., Sydow, K., Hirt, C., ... Bednarski, P. J. (2012). Identification of a glutathione peroxidase inhibitor that reverses resistance to anticancer drugs in human B-cell lymphoma cell lines. Bioorganic \& Medicinal Chemistry Letters, 22, 6712-6715. http://dx.doi.org/10.1016/j.bmcl.2012.08.091

Scofield, R. H. (2004). Autoantibodies as predictors of disease. Lancet, 363, 1544-1546. http://dx.doi.org/10.1016/S0140-6736(04)16154-0

Seifu, E., Buys, E. M., \& Donkin, E. F. (2005). Significance of the lactoperoxidase system in the dairy industry and its potential applications: a review. Trends in Food Science \& Technology, 16, 137-154. http://dx.doi.org/10.1016/j.tifs.2004.11.002

Serewko, M. M., Popa, C., Dahler, A. L., Smith, L., Strutton, G. M., Coman, W., ... Saunders, N. A. (2002). Alterations in gene expression and activity during squamous cell carcinoma development. Cancer Research 62, 3759-3765. PMID: 12097286

Shen, Q., Chu, F. F., \& Newburger, P. E. (1993). Sequences in the 3'-untranslated region of the human cellular glutathione peroxidase gene are necessary and sufficient for selenocysteine incorporation at the UGA codon. Journal of Biological Chemistry, 268, 11463-11469.

Shen, Q., Fan, L., \& Newburger, P. E. (2006). Nuclease sensitive element binding protein 1 associates with the selenocysteine insertion sequence and functions in mammalian selenoprotein translation. Journal of Cellular Physiology, 207, 775-783. http://dx.org/10.1002/jcp.206199_

Shin, K., Horigome, A., Yamauchi, K., Takase, M., Yaeshima, T., \& Iwatsuki, K. (2008). Effects of orally administered bovine lactoperoxidase on dextran sulfate sodium-induced colitis in mice. Bioscience Biotechnology Biochemistry, 72, 1932-1935. http://dx.doi.org/10.1271/bbb.70636

Shin, K., Tomita, M., \& Lonnerdal. B. (2000). Identification of lactoperoxidase in mature human milk.The Journal of Nutritional Biochemistry, 11, 94-102. http://dx.doi.org/10.1016/S0955-2863(99)00082-0 
Stagnaro-Green, A. (2004). Postpartum thyroiditis. Best Practice \& Research Clinical Endocrinology \& Metabolism, 18, 303-316. http://dx.doi.org/10.1016/j.beem.2004.03.008

Strieder, T. G., Prummel, M. F., Tijssen, J. G., Endert, E., \& Wiersinga, W. M., (2003). Risk factors for and prevalence of thyroid disorders in a cross-sectional study among healthy female relatives of patients with autoimmune thyroid disease. Clinical Endocrinology (Oxf), 59, 396-401. http://dx.doi.org/10.1046/j.1365-2265.2003.01862.x

Tang, N-P., Wang, L-S., Yang, L., Gu, H-J., Sun, Q-M., Cong, R-H., ... Wang, B., (2008). Genetic variant in glutathione peroxidase 1 gene is associated with an increased risk of coronary artery disease in a Chinese population. Clinica Chimica Acta, 395, 89-93.

Touch, V., Hayakawa, S., Yamada, S., \& Kaneko, S. (2004). Effects of a lactoperoxidase-thiocyanate-hydrogen peroxide system on Salmonella enteritidis in animal or vegetable foods. International Journal of Food Microbiologhy, 93, 175-183. http://dx.doi.org/10.1016/j.ijfoodmicro.2003.11.004

Ursini, F., Maiorino, M., Brigelius-Flohe, R., Aumann, K. D., Roveri, A., Schomburg, D., \& Flohe, L. (1995). Diversity of glutathione peroxidases. Methods in Enzymology, 252, 38-53.

Wirstam, M., Blomberg, M. R. A., \& Siegbahn, P. E. M. (1999). Reaction mechanism of compound I. formation in heme peroxidases: A density functional theory study. Journal of American Chemical Society, 121, 10178-10185. http://dx.org/10.1021/ja991997c

Woo, S., Yum, S., Park, H. S., Lee, T. K., \& Ryu, J. C. (2009). Effects of heavy metals on antioxidants and stress responsive gene expression in Javanese medaka (Oryzias javanicus). Comparative Biochemistry \& Physiology C, 149, 289-299. http://dx.doi.org/10.1016/j.cbpc.2008.08.002. Epub 2008 Aug 8

Wu, R., Shen, Q., \& Newburger, P. E. (2000). Recognition and binding of the human seleno-cysteine insertion sequence by nucleolin. Journal of Cellular Biochemistry, 77, 507-516. http://dx.org/10.1002/(SICI)1097-4644(20000601)77:33.0.CO;2-P

Xu, X. M., Carlson, B.A., Mix, H., Zhang, Y., Saira, K., Glass, R. S., ... \& Hatfield, D. L. (2007). Biosynthesis of selenocysteine on its tRNA in eukaryotes, PLoS Biology, 5, e4. http://dx.org/10.1371/journal.pbio.0050004

Yamamoto, K., Miyoshi-Koshio, T., Utsuki, Y., Mizuno, S., \& Suzuki, K. (1991). Virucidal activity and viral protein modification by myeloperoxidase: a candidate for defense factor of human polymorphonuclear leukocytes against influenza virus infection. Journal of Infectious Diseases, 164, 8-14. http://dx.doi.org/10.1093/infdis/164.1.8.

Zhang, L., Liu, X., Chen, L., You, L., Pei, D., Cong, M., ... Wu, H. (2011). Transcriptional regulation of selenium-dependent glutathione peroxidase from Venerupis philippinarum in response to pathogen and contaminants challenge. Fish \& Shellfish Immunology, 31, 831-837. http://dx.doi.org/10.1016/j.fsi.2011.07.026. Epub 2011 Jul 30.

Zhang, R., Brennan, M. L., Fu, X., Aviles, R. J., Pearce, G. L., Penn, M. S., ... Hazen, S. L. (2001). Association between myeloperoxidase levels and risk of coronary artery disease. The Journal of American Medical Association, 286, 2136-2142. http://dx.doi.org/10.1001/jama.286.17.2136

Zhang, T., Chabory, E., Britan, A., Grignard, E., Pitiot, O., Saez, F., ... Drevet, J. R. (2008). GPX5, the selenium-independent glutathione peroxidase-encoding single copy gene is differentially expressed in mouse epididymis. Reproductive Fertility and Development, 20, 615-25. http://dx.doi.org/10.1071/RD08008

Zheng, L., Nukuna, B., Brennan, M. L., Sun, M., Goormastic, M., Settle, M., ... Hazen, S. L. (2004). Apolipoprotein A-I is a selective target for myeloperoxidase-catalyzed oxidation and functional impairment in subjects with cardiovascular disease. Journal of Clinical Investigations, 114, 529-541. http://dx.doi.org/10.1172/JCI21109

\section{Copyrights}

Copyright for this article is retained by the author(s), with first publication rights granted to the journal.

This is an open-access article distributed under the terms and conditions of the Creative Commons Attribution license (http://creativecommons.org/licenses/by/3.0/). 